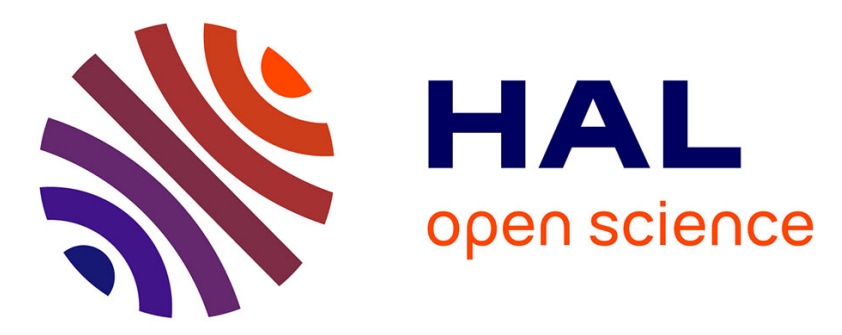

\title{
Power and Changing Riverscapes: The Socioecological Fix and Newspaper Discourse Concerning the Rhône River (France) Since 1945
}

\author{
Emeline Comby, Yves-François Le Lay, Hervé Piégay
}

\section{- To cite this version:}

Emeline Comby, Yves-François Le Lay, Hervé Piégay. Power and Changing Riverscapes: The Socioecological Fix and Newspaper Discourse Concerning the Rhône River (France) Since 1945. Annals of the American Association of Geographers, 2019, 109 (6), pp.1671-1690. 10.1080/24694452.2019.1580134 . halshs-02125902

\author{
HAL Id: halshs-02125902 \\ https://shs.hal.science/halshs-02125902
}

Submitted on 22 Jun 2021

HAL is a multi-disciplinary open access archive for the deposit and dissemination of scientific research documents, whether they are published or not. The documents may come from teaching and research institutions in France or abroad, or from public or private research centers.
L'archive ouverte pluridisciplinaire HAL, est destinée au dépôt et à la diffusion de documents scientifiques de niveau recherche, publiés ou non, émanant des établissements d'enseignement et de recherche français ou étrangers, des laboratoires publics ou privés. 


\title{
The socio-ecological fix and newspaper discourse concerning the Rhône River (France) since 1945
}

\author{
Emeline Comby_, Yves-François Le Laył, and Hervé Piégay \$ \\ Department of Geography, University of Bourgogne Franche-Comté \\ Department of Geography, University of Lyon \\ \#ational Center of Scientific Research (CNRS), University of Lyon
}

\begin{abstract}
Riverscapes are constructs that mix natural components with political, socio-economic, and technical strategies. This article shows how the riverscapes of the Rhône in France have changed under the influence of different power relations. We use newspapers to highlight the potential of news outlets as a data source with which to apply Foucault's critical and genealogical methods and to develop a political ecology of socio-ecological fixes. Media coverage is proxied by a content analysis and textual data analysis of 1,079 articles published in Le Monde, from 1945 to 2013. We study variations of newspaper discourse to create five chronological narratives: (i) the reconstruction of France and the creation of new landscapes, (ii) the promotion of national development through navigation, (iii) the quest for energy independence through dams and nuclear power plants, (iv) the abandonment of major projects, and (v) the definition of pollution and flooding as national problems at the same time as the rediscovery of landscapes as local amenities. River landscapes are related to national political objectives, even though schemes for the Rhône seem to be ever less geared to national ambitions. In specific contexts, bottom-up advocacy coalitions occasionally prove powerful enough to influence socio-ecological trajectories: their power seems to be on the rise as the national project wanes. They are often opposed to new socio-ecological fixes. While political drivers are instrumental in shaping the Rhône, economic dynamics are crucial. Energy production seems to be a good indicator for monitoring socio-ecological fixes along major rivers because it involves fixed capital.
\end{abstract}

Keywords

Construction of riverscape, discourse, political ecology, socio-ecological fix, temporal patterns. 


\section{Introduction}

Studies of political ecology (Bakker 2002), science and technology (Callon 1986), and critical physical geography (Lave et al. 2014) all share a combined focus on the relationship between social power and environmental change. Those studies examine the connection between landscapes and the power relations that shape them (Lave 2015). Landscapes are "humanely transformed nature", that is, nature transformed to serve some intended purpose (Mitchell 2003). O’Neill (2006) shows how political history and ideologies that consider rivers at a national scale greatly impact river development planning. Thus, legal discourse and political and economic contexts all influence riverscapes (Ashmore 2015). We consider riverscapes to be constructs that mix natural components with topical political issues, economic or social challenges, and technical strategies. Social construction, discourse, and scale are all reflected in riverscapes and in changing social relations (Budds 2009). Riverscapes can be seen as the outcome of socio-ecological processes throughout history (Boyer et al. 2018).

In France, hydraulic engineering may mirror state power (Mukerji 2009). This article aims to show how riverscapes on the French part of the Rhône changed under the influence of different power relationships after the Second World War (WW2). The Rhône drains a catchment area of 98,000 km² along its 718-kilometer course through Switzerland and France. In France, it has a 512-kilometer main stem flowing from Lake Geneva to the Mediterranean Sea. The Rhône has not been the subject of international disputes although it drains a watershed shared by Switzerland and France $\left(90,500 \mathrm{~km}^{2}\right.$ in southeastern France). Transboundary agreements existed on a sectorial basis (hydroelectricity) from 1970 to 2000 and attempts have been made to define new crossborder mechanisms between public authorities over the past decade (Bréthaut and Pfliger 2013). The two countries have developed different policies, which explains why the landscapes of the Rhône differ considerably between Switzerland and France. Here we focus exclusively on the French stretch of the Rhône.

In the nineteenth century, the Rhône was a free-flowing river often with multiple flow channels. However, its fluvial pattern began to change in 1860-1870 when the first embankments were built to improve navigation (Bravard 2010) (Figure 1). In the late nineteenth century, engineering structures known as Casiers Girardon and that look like groyne fields were built to narrow the Rhône's channel, concentrate its flow, and promote navigation. By 1945, 42 percent of the surface area covered by the Casiers Girardon was terrestrialized, and nowadays only 10 percent is still aquatic (Thorel et al. 2018). During the nineteenth century, navigation was the main strategy for economic development. That strategy produced geomorphological and ecological responses during the twentieth century. After the Liberation of France in 1944 and the end of WW2 in 1945, the Fourth Republic was founded. The Rhône's riverscapes served to rebuild the political authority of central government and to promote economic development. In 1957, the Treaty of Rome created the European Economic Community and fostered new economic partnerships. The 1950s and 1960s saw the end of the French colonial empire, in some places through relatively peaceful decolonization, in others through war. It 
was during the Algerian War of Independence that de Gaulle created the Fifth Republic in 1958. These geopolitical issues (European construction and the end of the colonial empire) highlighted the use of the Rhône for transporting goods.

Even so, the Rhône has had new uses ever since 1945. The current complexity of its riverscapes arises out of the many functions assigned to the Rhône since WW2 and the changes to them over time. After WW1, an Act of Parliament of 1921 suggested three ways to develop the Rhône valley and indirectly the rest of the country: navigation, hydroelectricity, and irrigation. In 1933, the state created the Compagnie Nationale du Rhône (CNR) to carry out this program. However, before WW2, nothing had really changed. Then, from 1945 to 1986, the CNR constructed 19 dams to produce hydroelectricity, to ease navigation, and to irrigate agricultural land. Currently, the CNR generates 25 percent of France's hydroelectricity. At the beginning of the twenty-first century, four nuclear power plants (out of a total of 19 in France) draw water from the Rhône to cool their reactors. Electricité de France (EDF), the national power company, produces 22 percent of France's nuclear energy along the Rhône (Figure 2). Currently, the Rhône valley forms one of France's major transportation routes (highways, high-speed railroads, and pipelines). A number of large urbanized areas are strung out along the valley: Lyon (France's second largest urban area), Valence, Montélimar, Orange, Avignon, and Arles. We take a retrospective approach to examine the Rhône's riverscapes after WW2 within the framework of the socio-ecological fix. Different approaches to fixes coexist in the literature: fixes are increasingly common in critical geography. Bok (2018) describes the fix as "a pliable enough metaphor, [...] a chameleon-like character", which was used in the 1980s as a "spatial fix" by Harvey, then in the 1990s as a "spatio-temporal fix" of regulationist-theoretical approaches, in the 2000s as a "scalar fix" of state rescaling theory, and finally in the 2010s as the "environmental fixes of politicalecological approaches". Yet, in 1967, Weinberg had already pointed out that solving problems by technological fixes is a less "hard business" than solving them by social changes: technological engineering is expensive to develop, but readily successful. In critical geography, a fix generally denotes a reproduction of capitalism that entails iniquities, and such reproduction is due to different negotiations and arrangements, despite crises (Castree and Christophers 2015). After Harvey (1996, 2001), Ekers and Prudham (2015) insist on a spatial fix defined as "an intensive and extensive transformation of landscapes and processes", an entangled production of space and nature. The socioecological fix explores "the ways in which crises of capitalist overaccumulation might be displaced through spatial fixes that result in the production of nature" (Ekers and Prudham 2017). Moreover, Swyngedouw (2014) also insists on the spatial and scalar dimension of a fix in developing the concept of the hydroscalar fix: despite crises, the economic challenges of capitalism generated the growth or the reproduction of the same model of water development. The economic system was not in question: it was developed elsewhere (and sometimes differently) and it transformed ever more space and nature. Concerning the socio-ecological fix, Ekers and Prudham (2015) add another component associated with social issues and that entails "shifts in the social regulation of productions of space and 
nature in response to real and perceived crises of legitimacy". Furthermore, Swyngedouw (2013) insists on this social dimension of the fix and shows that a hydro-social fix reproduces the hegemony of a few stakeholders, the most powerful (and often the richest) actors. Our case study illustrates our interest in the framework of the socio-ecological fix considered as a synthesis of these different approaches to fixes based on the technological, spatial, scalar, and social consequences of economic crises. Cohen and Bakker (2014) argue that the fix displaces conflicts and crises, often through the construction of ecological scales, "which simultaneously depoliticize and repoliticize governance". We also insist on another dimension of socio-ecological fixes by taking into account the ways in which riverscapes are produced politically.

Ekers and Prudham (2015) emphasize that "little scholarship [...] has systematically developed [...] a political ecology of capitalist crises, that is the role of socio-natural transformations" in (re)producing accumulation. We seek to understand broader trajectories of socio-natural change of the Rhône's riverscapes since 1945. Frioux and Lemire (2012) explain that the 1970s are often considered as a new political and environmental moment in French environmental history, but the origins of this moment and even more the post-1970s are frequently forgotten: they evoke "a chronological myopia". Pritchard (2011) has already drawn attention to the joint construction of the Rhône and of society based on historical archives and on the concepts of science and technology studies. In this paper, we emphasize the power relationships linked to the conceptual framework of political ecology (Swyngedouw 1999). This implies focusing on the various political and economic actors and the interests they defend, as well as on the discourses establishing the current understanding of the themes and problems involved. We shed light on the different physical and discursive constructions of the Rhône's riverscapes over 68 years, from 1945 to 2013.

Our first hypothesis assumes that the Rhône has undergone many changes, primarily due to different top-down decisions made at the national level since 1945. Our second hypothesis considers that the Rhône's riverscapes have been shaped by capitalism and its crises since 1945 .

\section{Discourse, social problems, and policies}

Discourse, considered as a practice with material consequences, can be explored to study the overlap between social and natural components (Bakker 1999). Representation and discourse analysis explain a way of being, living, and speaking (Foucault 1966). Knowledge, discourse, and practice are situated in power relationships (Swyngedouw 2015). Considering discourse as a social act, Fairclough (2010) adopts a three-scale approach: a micro-approach based on words; a meso-approach based on the production, circulation, and reception of discourse; and a macro-approach based on the social construction of discourse (production and reproduction in society). As explained by Smith and Joffe 
(2009), three information sources contribute to public knowledge: experience, social relationships, and the media.

Newspapers are convenient sources of information for understanding how past reality was built, without any memory bias (Gregory and Rowlands 1990; Vuorisalo, Lahtinen, and Laaksonen 2001) and with a record over quite a long period (Ibsen and Brunsden 1996). Despite their use of personalization, dramatization, and novelty (Boykoff and Boykoff 2007), the media play a major role in mediating between science, policy, and the public (Lester 2010; Boykoff 2011). Media discourse can offer a "critical" perspective that "distinguishes the forms of exclusion, limitation and appropriation" and a "genealogical" approach that examines "how series of discourse are formed, [...] what were the specific norms for each, and what were their conditions of appearance, growth and variation" (Foucault 1971). From a Foucaldian perspective, we use newspaper discourse to highlight the potential of news outlets as a data source for developing critical and genealogical perspectives and for developing a political ecology of socio-natural changes and socio-ecological fixes.

Some stakeholders consider socio-ecological fixes to be a solution to various social problems. A social problem is "a putative condition or situation that is labeled a problem in the arenas of public discourse and action" (Hilgartner and Bosk 1988, p. 55). Discourse witnesses and (re)produces social problems. After selection and competition among different issues (for example floods, biodiversity, droughts, etc.), social groups recognize certain situations as problems; this explains the rise and fall of social problems. The scope and speed with which a social problem develops can be explained by the forms in which the problem is expressed, its subject matter, and the intensity of the interest it elicits. A social problem may entail political decisions and choices when different actors share the same definition of a social problem (such as the development of a river) and come together to make their voices heard (Comby, Le Lay, and Piégay 2014b). To explain how an arena can become powerful enough to make policy changes, we use the advocacy coalition framework (ACF).

Sabatier (1988) develops the ACF which insists on the requirement of a time perspective of at least one decade in order to understand the process of policy change and to obtain a worthwhile assessment of policy impacts. A policy involves priorities as to values, perceptions of current problems, causal relationships, and requires effective policy instruments. Actors are grouped into many arenas which may become an advocacy coalition. The members of an advocacy coalition share a set of normative beliefs about the world and perceptions of it, and they act together to translate their beliefs into public policies. The conceptual framework of the ACF is based on two types of indicators: relatively stable parameters (attributes of the problem, distribution of natural resources, values, structures) and external events (socioeconomic conditions, public opinion, etc.). Through their modification, relatively stable parameters and events are able to bring about political changes despite coalitions of actors operating over the long term. The biophysical characteristics of the river system, water resources, economic structures, and public perceptions may be considered relatively stable parameters (Sabatier and Jenkins-Smith 1993). Such parameters constrain the political subsystem, which is itself made up of 
various advocacy coalitions. The latter may influence the political subsystem and change certain environmental perceptions (Comby, Le Lay, and Piégay 2014a). Initially, proponents of ACF suggested that external events were more likely to change the system and generate top-down policies. However, this framework has become more complex. A second, more endogenous set of factors seems able to change those core beliefs: a situation of a damaging stalemate in which everyone considers the status quo to be unacceptable; participation by stakeholders; decision rules based on consensus; time; a competent policy broker; mutual trust; and learning among coalitions (Sabatier 2010). Advocacy coalitions propose different physical and discursive constructions of riverscapes over time. Indeed, advocacy coalitions themselves rise and fall over time. The shift from one social problem to another reflects and (re)produces the power relationships among different advocacy coalitions. We attempt to identify different periods to reveal the changes in topical issues, the power relationships between different advocacy coalitions, and their political and physical consequences for the Rhône River.

\section{Material and methods}

A corpus: The Rhône River in Le Monde (1945-2013)

The principal dataset addresses the description and the perception of the Rhône River in the national daily newspaper Le Monde. Merrill (2000) explains that Le Monde is one of the world's great newspapers because of the quality of the information it provides, its editorial freedom, its detailed analyses, its sparing use of pictures, and its un-spectacular approach. This newspaper has already been used by researchers such as Brossard et al. (2004) to represent the French point of view on climate change. We chose Le Monde because it was created in 1944, towards the end of WW2, enabling us to work on almost 70 years with the same proxy as part of a retrospective approach. In 2013, Le Monde was France's second best-selling national newspaper. The size of its readership underlies its legitimacy as a provider of data.

We collected newspaper articles from two digital databases: the first is made available by the newspaper itself and allows subscribers to request articles; the second is Europresse. We searched for the word "Rhône" from 1945 to 2013. This involved sorting through a huge number of articles because "Rhône" forms part of the name of an administrative region (Rhône-Alpes), and it is also the name of two lower tiers of government (département and commune). The final raw material comprises 1,079 articles published from 1945 to 2013.

\section{Methods: a critical discourse analysis}


We used a mixed method combining content analysis (Berelson 1952) and textual data analysis (Lebart, Salem, and Berry 1998). Content analysis includes qualitative data in a quantitative form (Hayward and Osborne 1973). After reading each article, categories were created to gather the information from each item (Boholm 2009). This standard method enables investigators to compare

228

229

230

231

232

233

234

235

236

237

238

239

240

241

242

243

244

245

246

247

248

249

250

251

252

253

254

255

256

257

258

259 different texts (Mayring 2000). To avoid intercoder variability, one analyst read all the texts and coded certain categories, such as the main themes of each article.

To supplement this, lexicometric analyses consider graphical forms only such as words (Lebart, Salem, and Berry 1998). Textual data analyses created in the 1970s were based on inferences and interpretations of statistical results of texts (Benzécri and Benzécri 1980). We used the TXM opensource platform (Heiden 2010) and IRaMuTeQ software (Ratinaud and Marchand 2012) to perform our textual data analyses. IRaMuTeQ reproduces the top-down classification developed by Reinert (1983); this method creates text segments, performs lemmatization, and then proposes different statistics (Cottet et al. 2015).

We combined these analyses with a qualitative approach through different quotations to create narratives. These methods replace the three tools (the saw, the wedge, and the axe) described in the famous "allegory for historians" of Leopold (1949) when he cut down his "good oak" (showing 80 growth rings). They allow us to operate across the years (like the saw) and to work in radial splits (like the wedge) but also to function at a diagonal angle to the years (like the axe).

\section{Results: Building a "new" Rhône River}

Temporal variations in newspaper discourse on the Rhône River (1945-2013)

An average of 16 articles about the Rhône River were published per year, with a fairly wide range from 2 to 46. While the number of publications in Le Monde was high until the end of the 1970s, the frequency tended to decline afterwards (Figure 3). The median number of articles was reached in June 1975, reflecting a concentration of publications at the beginning of the period. In three separate years, more than 40 articles were published: in 1975, 1960, and 1955, in decreasing order of appearance. In 1955, flooding was the main theme, with a secondary topic being dams. In 1960, articles mostly focused on the Rhine-Rhône Canal and the irrigation of the lower Rhône valley (Bas-Rhône). Lastly, in 1975, articles mainly revolved around the controversial Rhine-Rhône Canal and water pollution. Since 1983, the number of annual occurrences has tended to be low, with the exception of 1987 and four periods, 1993-1994, 1996-1997, 2000-2003, and 2007-2009. These four phases correspond to flooding, the abandoning of the Rhine-Rhône Canal project, and PCB (Polychlorinated Biphenyl) pollution of the Rhône. National media coverage of the Rhône during the last thirty years has been 
because of major crises. Consequently, we observe a decline in the number of articles relating to the Rhône.

A total of 431 articles focus on navigation, 205 cover flooding, 154 are about dams, and 104 address pollution (Figure 4). Other themes are prominent in fewer than 35 articles. These topics show a wide interannual variability from 1945 to 2013 (Figure 5). Navigation was found to be the main theme from 1959 to 1997 . The second most frequently mentioned topic (floods) was very regularly quoted from 1950 to 1971; this topic then became more discreet until it made a comeback in media coverage from 1990 to 2004. Dams were a key theme from 1945 to 1957 (with maxima in 1945, 1946, and 1948), from 1965 to 1971, from 1979 to 1984, in 1987, in 1993, in 2000, and in 2010. Lastly, pollution is frequently mentioned between 1960 and 1986, with peaks in 1976, 1977, 1986, and from 2007 to 2011. Waterfront redevelopments emerged as a major theme in the 1980s and from 1999 to the end of the period.

\section{An (inter)national development}

Using IRaMuTeQ, a clustering tree (Figure 6) is structured around three main poles: (i) the first emphasizes environmental risks such as flooding and protection of the Camargue (classes 6 and 7), (ii) the second is organized around three economic functions of the Rhône (classes 1, 2, and 5), and (iii) the third presents the main stakeholders in the Rhône and public debate (classes 3, 4, and 8). Despite changes in environmental dynamics, society cannot tame the Rhône. Class 6 addresses biodiversity and sheds light on a unique place: the Camargue at the heart of the Rhône delta. Class 7 handles flooding, including descriptions of situations, damage, and comparison with other rivers. Three functions are central: energy (class 5), navigation (class 2), and the industrial development of the Rhône valley (class 1). The Rhône River landscapes are linked to reconstruction, industrialization, and the quest for energy independence in postwar France. The Rhône River landscapes are created by policies (classes 3, 4, and 8). The State is prominent in class 3. Class 4 insists on a greater diversity of levels of decision-making within communes, departments, and regions. Class 8 focuses on environmental degradation and debate linked with this new design through two topics: pollution and waterfront redevelopments.

We focused on place names mentioned more than 50 times. The spaces specifically mentioned are mostly outside the Rhône watershed. Figure 7 shows 33 toponyms far from the Rhône, while 28 toponyms are along the Rhône. The Rhône appears as a resource from an exogenous perspective. The national scale plays an important role through the terms 'France' and 'Paris'. An overrepresentation of the East of France appears with Alsace, Moselle, Strasbourg, Doubs, East, Lorraine, Mulhouse, Franche-Comté, and Besançon, which may extend to a European perspective with Germany and Switzerland. In the same way, although France's other major rivers all appear, the easternmost of them, the Rhine, is the most cited. Another axis emerges, namely, the Rhône-Mediterranean, which 
connects southern "poles" such as Marseille and Fos-sur-Mer to broader European dynamics. Lastly, non-French toponyms are located in Europe, in Switzerland (Geneva or Lake Geneva) and highlight European spaces with a certain economic prosperity, such as Rotterdam, Europe's leading port, and Germany.

\section{Rhône River narratives combining time and space}

Reconstructing France and developing the Rhône River (1945-1960)

WW2 entailed a multifaceted crisis: (a) international competition was essential to understanding the CNR project and dam construction to ensure the nation's renewed geopolitical influence and economic development; (b) nationally, the presidential function had to be reaffirmed to rebuild the state's authority; and (c) economically, energy was in too short supply to ensure new economic prestige. The capitalist system became both a political and economic project based on dams. From 1945 to 1960, 284 articles were published. Of them 35 percent covered floods, 29 percent were about dams, and 23 percent discussed navigation.

After WW2, the Rhône River project was based on a U.S. model. The New Deal was seen as a policy that was easy to replicate. Water was a resource that could be used to lift the country out of its economic crisis. Although the CNR was created by the 1921 Act, the Tennessee Valley Authority (TVA) set up in 1933 served nevertheless as a benchmark for it. Le Monde compared the CNR to the TVA 21 times. "The Rhône River has the biggest lock in the world. The development of the middle reach of the Rhône River between Donzère and Mondragon will have considerable consequences for agriculture as for industry throughout the southeast. This huge undertaking is, at the European level, what the planning of the Tennessee Valley was to the US" (Le Monde, 8 June 1948). Furthermore, in 1936 Franklin D. Roosevelt nicknamed CNR president Léon Perrier the "Father of the Tennessee Valley Authority" (Bethemont 1972). The circulation of ideas across the Atlantic Ocean was facilitated by two books published after WW2 in France. First, J. Huxley wrote TVA: Adventure in Planning, the 1944 French title of which was La Vallée du miracle. "TVA", une aventure dans le domaine de l'économie planifiée. Then, D. E. Lilienthal published in 1944 TVA: Democracy on the March. The TVA aimed at promoting flood control, electrification, rural development, and conservation (Pritchard 2011), whereas the CNR had three objectives: hydroelectricity production, improvement of agricultural methods (such as irrigation), and navigation. "From Tennessee Valley Authority dams to the Donzère-Mondragon project. There are few American institutions which are as well known and so poorly known, [...] as the famous Tennessee Valley Authority. [...] Two small books published after the Liberation (Julian Huxley's Valley of the Miracle, and David Lilienthal's TVA) made known to the French public this work of truly American proportions" (Le Monde, 20 August 1949). The construction of multi-purpose dams explained the comparison. Moreover, 
journalists seemed to be fascinated by the United States and the importance of the economic and landscape changes there. The flow of capital was also linked with the United States: Marshall Plan funds helped to build dams. Pritchard (2011, p. 72) suggests that this story often went unreported in order to distance "the project from its financial dependency on the United States and consequently reinforced its supposed 'Frenchness"'. Nevertheless, the journalists of Le Monde did not ignore this point: from 1948 to 1957, the Marshall Plan was referred to nine times. The United States also appeared as a competitor to France's international standing ("rayonnement") (Pritchard 2004). Journalists focused on the potential narrowing of the development gap. The development of the Rhône involved shared interests and joint capital investments between France and the United States. The projects for the Rhône were indicative of relations between France and the United States after the war. The Rhône provided the image of an economic and political resource that reaffirmed France's international prestige. Le Monde highlighted presidential visits, such as Tito's in May 1950 and Khrushchev's in March 1960. The Rhône was the subject of curiosity for tourists looking to visit a changing France. In March 1956, 22 German journalists came to witness and report back on the river's development. The Rhône was one of the prime places for admiring the post-war reconstruction of France, which while reasserting the authority of central government was also creating dependence on the U.S. economic model.

The development of the Rhône became a symbol of national reconstruction and promoted France's image abroad. The inscription "The Rhône in the service of the nation" on the Seyssel dam still testifies to how the national project for developing the river was intended to entrench the state's authority. The presidents of the French Republic also played a prominent part in re-envisioning the Rhône River: Auriol (1947-1954) was mentioned 25 times, Coty (1954-1959) 6 times, and de Gaulle (1959-1969) 27 times. Politicians used the engineering achievements on the Rhône for grandstanding. Auriol affirmed in Génissiat: "Produce and rebuild: Between a sharp decline and rapid revival there is no intermediate solution" (Le Monde, 3 August 1948). In 1947, Gravier published Paris et le désert français [Paris and the French Desert], which highlighted the need to reduce spatial and economic disparities between regions. The Rhône was the emblem of state interventionism in an unusually centralized country, because political and economic strategies were intertwined. Rhône River planning was a top-down policy: it aimed at striking a better balance in national development by industrializing the Rhône valley. Some of its inhabitants were members of the CNR, such as its president, Perrier. Herriot, the mayor of Lyon, was one of the leading supporters of the project. The shareholders of the CNR were the city of Paris, 14 départements, several cities along the Rhône valley, a railroad company, and various manufacturers. The state itself though not a shareholder still played an important role (Giandou 1999). These ex nihilo constructions came in for criticism: "French industry's needs are very important. But we should not fall into what is called the snobbery of kilowatts. Dam construction removes villages; it disturbs the tranquility of working populations. Yesterday Tignes was sacrificed. The creation of Donzère-Mondragon damaged some of the neighboring populations" 
(Le Monde, 18 February 1954). The development of the Rhône symbolized the assertion of state authority, even though the CNR involved both national and local stakeholders.

From 1945 to 1960, the CNR built five dams and created a new pattern of landscape. A diversion dam split the Rhône into a by-passed main channel (sometimes called the Vieux Rhône [Old Rhône River]) and a new canal with a hydroelectric power plant. These landscapes bear witness to the role of WW2 in socio-natural transformations and the creation of a resource through the accumulation of economic capital. This is our first socio-ecological fix based primarily on a technological fix. Many other dams were planned at the time and built in the next period.

Promoting national territorial development and improving navigation (1961-1972)

As of 1961, the main topic was different: 34 articles were published in 1961, 27 of which concerned navigation. From 1961 to 1972,58 percent of articles were about navigation. The crisis was linked with economic and political drivers: energy prices, decolonization, the creation of a European common market, and the ideology of aménagement du territoire national [French national planning] to reduce uneven national development. As oil prices were low, hydroelectricity was less profitable. Le Lannou, a geographer at the University of Lyon, affirmed that "electricity is no longer able to finance large investments. We must therefore provide a development method for multiple purposes, no one service of which is profitable in itself, whereas together they make for a very worthwhile investment" (Le Monde, 31 July 1972). Two new main objectives were developed both with a European ambition: (i) to make the Rhône River navigable by larger vessels within a continuous network of wide-gauge waterways, and (ii) to build the Rhine-Rhône Canal.

Locks were built to open a waterway connection between Lyon and Marseille. Navigation was seen as a means of developing southeastern France. First, at national and regional scales, central government decided that Lyon and Marseille were métropoles d'équilibre [i.e. metropolises that could counterbalance the domination of the capital city Paris and develop their regions through knock-on benefits] to reduce uneven development. In the 1950s and 1960s, F. Perroux's growth pole theory was widely discussed in France: it argues that economic development depends on different poles (or clusters) and growth industries located in different regions. Thus the creation of an economically dominant region was based on propulsive industries, that could engender positive externalities—what he called effet d'entrainement ["propulsive effect"] —and consequently economic growth. The Rhône valley is the extended region of two "countervailing" metropolises, Lyon and Marseille. Then, internationally, the closure of the Suez Canal (from 1967 to 1975) and decolonization invited actors to look less to the Mediterranean Sea and more toward northern and eastern Europe, especially to Germany. The development of a common market since the 1950s and the prosperity of certain economic areas also explain this shift. The Rhine-Rhône Canal was the missing link in the Europeanwide waterway and could help the economic development of the "countervailing metropolises". The 
French president was committed to the Rhine-Rhône Canal project. Mayors of certain cities in the hinterland of the Rhône lobbied extensively, including Defferre, mayor of Marseille, and Pflimlin, mayor of Strasbourg. In response to Defferre, President de Gaulle suggested: "Marseille has no reason to fear the future in regard to the Canal, it is indeed a necessary decision. We made the decision to construct it. As soon as the current studies have been completed, the connection will be made" (Le Monde, 13 November 1961). However, this project was very expensive. Navigation as a profitable venture was increasingly criticized at a time when sections of the A7 highway and the pipelines along the Rhône River were earning a reputation for technical advancement.

The urbanization and industrialization of the Rhône valley generated problems. The issue of water treatment was becoming more prevalent in the 1960s: could the Rhône be an open sewer? The 1964 Water Act meant water quality was emerging as a major concern: the Rhône, polluted as it was by industrial and domestic waste, did not have a good record. The Conseil supérieur de la Pêche [National Fishing Council] stigmatized the chemical plants within Lyon's urban area. "The Rhône River carries those masses of red or blue foam, depending on the day, in waste from riverside plants" (Le Monde, 16 June 1972). The urbanization and industrialization of the Rhône valley led to a degradation of water quality.

Moreover, nuanced discourse on dams seemed to increase. Locals felt dispossessed. Farmers sometimes expressed their disapproval, notably at the time of a violent expropriation operation in March 1968 in Avignon, which delayed some dam constructions. Similarly, in September 1971, two brothers kidnapped a CNR employee so as to secure higher compensation. These two news stories were isolated events but reflected local anger at the loss of good farmland. These examples also show ambivalence between the desire to develop an irrigated and productive agriculture and the sacrifice of farmland. The management strategies of central government were questioned at the local level because of the awareness of consequences, the refusal of new disturbances, and uncertain economic equilibria. However, although the construction and reproduction of similar landscapes along the Rhône were the subject of negotiations with various local political actors, they illustrated the triumph of a national project. Energy prices played a significant role in this new socio-ecological fix. This fix was mainly based on a hydroscalar fix (the creation of a homogenized valley linked with Europe) and a technological fix. The redevelopment of the Rhône re-envisioned it as a canal which would help the economic development of outlying parts of the nation thanks to navigation. This development was viewed from a European perspective at the time of decolonization.

Achieving energy independence and seeing the Rhône disappear (1973-1981)

From 1973 to 1981, navigation was the main issue, featuring in 62 percent of news items. Pollution became topical (17 percent of articles). In 1974, the first article to tackle nuclear energy was published. From 1973 to 1981, 13 percent of articles cover energy issues (dams and nuclear power 
plants). The 1973 and 1979 oil shocks led to higher heating prices, with two consequences for the

Rhône: the renewed importance of hydroelectric projects and the affirmation of nuclear energy as a solution. This international crisis entailed a socio-ecological fix, i.e. the production of new landscapes (nuclear riverscapes) and the reproduction of a familiar riverscape (dams and canals).

This public perception was not unanimous, since the last lock on the Rhône River was implemented in 1980. "This is another Rhône River. The eyes get used to it, and even better, it will be less and less the memory of what was. [...] We have mollified the Rhône" (Le Monde, 1 October 1979). The use of the term "river highway" reflected this straightening of the Rhône: some actors used the metaphor of the staircase to evoke its dams. It also echoed the development of automobile traffic in the Rhône valley, a sign of the country's modernization and unification. It entailed a standardization of landscapes, in which local peculiarities were erased in favor of a national (or world) view of what a navigable river should be. The new banks lined an easily navigable and so more profitable route: time was saved, and the standardization of the fleet and harbor facilities limited the effects of transshipments. On the 22 June 1972, French author B. Clavel explained in Le Monde: "I have no illusions. I know very wellthe entire history of mankind is there to teach us-that never have painters, poets, songwriters, writers or lovers of nature triumphed over politicians allied with bankers and merchants. In a word: neither reason nor good feelings can triumph over money. [...] I saw the Rhône River die, my second home, and I now hear the complaint of residents who did nothing to save it. I hear the boatmen cry still. They killed it". Clavel emphasized the political and economic shaping of the Rhône and the disconnection between national objectives and an almost visceral local attachment to its lost landscapes. Such words are emblematic of the awareness among some local players that the Rhône was gone and had been sacrificed for "the lies of the nation state", to use one of Clavel's expressions. The arrangements of previous periods seemed to have been destabilized.

The 1970s oil crisis prompted the French state to rethink the national energy mix and legitimized the hydroelectric development of the Rhône, which had previously been considered uneconomic. The new dams - Caderousse in 1975, Avignon in 1973, and Vallabrègues-Arles in 1973 - were less grandiose constructions. However, specific criticisms emerged about the impact of development on the ecology and landscapes of the river: central government planning increasingly encountered regional and local opposition. Despite these reservations, ongoing projects were accelerated and suspended projects resumed. Thus, the development of the Rhône was not linear over time but occurred in fits and starts dictated by a political and economic rationale. This politico-economic outlook saw dams as things of national utility and the Upper Rhône as under-exploited. Accordingly, the dam at Chautagne was built in 1980 and five other dams planned. Nuclear energy also appeared as a solution to the oil shocks. Environmentalists and some scientists warned of the issue of thermal pollution, one of the arguments against nuclear power plants. Despite criticism or nuanced positions, Creys-Malville, Bugey, and Tricastin were the first constructions in what would become the world's most heavily nuclearized valley. Hydroelectric and nuclear energy became the new means of restoring France's prestige and 
independence. These new constructions depended on the river's economic stakeholders: the CNR in conjunction with Swiss energy stakeholders for dams and EDF for nuclear power plants.

Local mobilization (with environmentalists, scientists, anglers, and local elected officials) might promote new standards, regulations, or alert levels to produce another idea of the river, thereby reducing the damage done (e.g. during dam flushing) by serving political and economic precepts alone. Meanwhile, local discourse on pollution and on the deterioration of the river more generally proliferated and was very much present at national level. Vallin and Porelli were both mayors and presidents of associations who successfully federated local councils to transform local mobilization into regional commitment. Local stakeholders tried to change perceptions of the Rhône to stop further damage to it. Industrial accidents, particularly in the chemical sector near Lyon, highlighted the Rhône's pollution problems. Industrial discharge had a very visible effect on the river. "We fished 367 tons of dead fish over dozens of kilometers downstream from Lyon, and angling federations of five départements have brought civil action in this case" (Le Monde, 27 April 1977). The courts found a company liable. This ecological disaster in 1976 marked a turning point: economics did not justify uncontrolled spillage and an absence of liability. This naming and shaming over pollution of the Rhône was also highlighted nationally by the consequences of the damage for the Mediterranean Sea. The Mediterranean benefits from major commitment in terms of the fight against pollution because of the place it holds in peoples' imaginations and its symbolic status in history, the mobilization of economic actors in fisheries and aquaculture, and geopolitical relations among the various coastal states. Local mobilization was structured around the Rhône to put an end to noticeable local pollution. The last lock on the Rhône, new dams, and new nuclear power plants were evidence of this socioecological fix through technological and hydroscalar fixes. Landscape changes entailed local mobilization that was very much present but not all-powerful. Power relations were to change in the next period.

Abandoning major development projects and not taming the Rhône (1982-1997)

From 1982 to 1997, 209 articles were published. Of these 46 percent addressed navigation. Eighteen percent of the articles covered floods: from 1966 to 1982, only seven articles had been about floods. Eleven percent of the articles dealt with pollution and 10 percent referred to energy production (mostly dams). The crisis was due to a local refusal of new intensive transformations of landscapes. Capitalism was in competition with other values such as nature, landscapes, and a sense of place.

Although the state had appeared favorable to the Rhine-Rhône Canal in the previous periods, a change in the parliamentary majority and the coming to power of the Jospin government in June 1997 saw the Socialists and the Greens criticize the project. A top-down decision sealed the fate of the Rhine-Rhône Canal project, which was no longer seen as a development in the national interest. Barthélémy (2006) claims that this decision might have been connected to the Rhône's 10-year program of hydraulic and 
ecological restoration: out of 39 persons interviewed, 12 believed that this program was linked to the abandonment of the Rhine-Rhône Canal, which was seen by some as a victory by others as a defeat. After 1997, media coverage of navigation was very limited: from 1998 to 2013, only eight articles about navigation were published. Clearly the end of plans for the Rhine-Rhône Canal meant the river was less newsworthy.

Local criticisms were exacerbated by the return of repeated flooding, which seemed to have been forgotten in the previous period. Although the dams on the Rhône were not designed for flood management, residents still felt protected. After 30 years without notable events, the floods of 1990, 1993, and 1994 were a reminder of the dangers of living near such a river. "We were scared; we felt powerless in front of this body of water [...] The Rhône was tamed, they said, but if the Rhône River wanted to be nasty, nothing stopped it. We had already seen it angry, that was perhaps forty years ago; we forgot it, but it reminded us" (Le Monde, 11 October 1993). By increasing channelization and restricting its natural corridor, the Rhône had been made more dangerous. In addition, the dikes, some of them old, had not always been maintained and failed to serve their main purpose. Restoring the river's original course would be one way to manage the rising waters. Fast-growing urbanization increased vulnerability. Consequently, although these floods were normal occurrences, they were perceived as unexpected and as different from the events people had already experienced: the damage caused was a reminder of the risk run.

This period was marked by the announcement of new dams on the Rhône, with four constructions programmed upstream from Lyon. National perceptions affirmed the need to use every drop of water so as not to waste money (even though this manna was a fiction in the absence of dams). However, these constructions met with strong local reticence: some advocacy coalitions managed to influence projects at a time when public inquiries became mandatory and when local mobilization was strong. Local actors refused to make fresh sacrifices for the nation. Ecological impacts were increasingly taken into account thanks to an environmental coalition. This episode coincided with the strengthening of a coalition that had first appeared during the previous period. It brought together scientists, environmentalists, anglers, and local politicians, and together they obtained an increase in minimum flow. The Rhône dam chain was only partially completed: Sault-Brénaz was considered as the last major project on the Rhône, a status conferred by the abandonment of the Loyettes and Miribel-Thil projects.

Thus, the accelerating nationwide demand for river development was confronted with local refusal. Despite sporadic local mobilization since the 1960s, power relations were not disrupted until the 1980s. This powerful coalition was indicative of a change in perception: the Rhône could not be seen as merely serving the nation and as a subject of top-down policies. However, the socio-ecological fix did not stop and was still noticeable in the creation of dams and nuclear power plants, both technological and hydro-scalar fixes. 
Media coverage decreased in this period with only 152 articles published. They dealt with floods (47 percent of news items), pollution (19 percent), energy (13 percent), and the rediscovery of urban waterscapes (10 percent). The topics were more diverse than in the previous periods. External parameters seemed to be weaker. The crises were due to the rediscovery of historical pollution and the degradation of urban riverscapes.

563 The issues involving the Rhône prompted the state to reformulate its policy on flood management and 564 PCB pollutions. Repeated flooding in France in 2000, 2001, 2002, and 2003 had serious

565 consequences. Following the 2002 floods, R. Bachelot, Minister for Ecology and Sustainable Development, promised a new risk-based law in France to be enacted in 2003. Furthermore, the rediscovery of PCB pollutions of the Rhône between 2005 and 2007 led to fresh analyses of other French rivers and the discovery of a national issue. This gave rise to a national plan against PCB pollutions in France's rivers (Comby, Le Lay, and Piégay 2014b). Thus, the Rhône revealed certain failings in national policies with regard to rivers.

The "rediscovery" of the Rhône involved a revaluation of these landscapes locally. Urban waterfront redevelopment projects multiplied. The river came to be seen as an attractive resource for cities looking to be competitive in terms of metropolitanization but also to improve the quality of everyday life of their inhabitants. The proposed reorganization reflected nostalgia with automobile amenities (such as parking lots and roads) being replaced by facilities for leisure and tourism. Waterfront redevelopment coexisted with the issue of pollution. Better water quality made it possible to rediscover the river banks. The aim was to turn water into an attractive resource. Landscapes became prominent local features, but this should be viewed in the context of a time when a growing number of cities were using waterfront redevelopments to become more attractive.

During this period, crises were related to earlier strategies to industrialize and urbanize the Rhône valley (especially pollution and waterfront development). The Rhône riverscapes were produced by a techno-managerial fix. The primary scale seemed to be the local level although it was intertwined with national decisions. Yet, this finding must be put in perspective: media coverage of issues involving the Rhône was very low during this final period. Consequently, even the issues cited most often received comparatively little coverage.

\section{Discussion}

\section{Developing a national river: top-down policy and major rivers}


592 We show that river landscapes are linked to political objectives. This top-down policy gives rise to 593 local opposition and conflict that only partly confirm our first hypothesis. Different powers exist, and 594 in specific contexts, occasionally, bottom-up advocacy coalitions can be powerful enough to influence 595 socio-ecological trajectories.

596 After WW2, the reconstruction and modernization of France was partly based on the construction of 597 new Rhône River landscapes. The Rhône embodied a political will that was materialized through 598 planning and actions carried out mainly by the state. This chronology corresponds to that established 599 by Swyngedouw (2015) for Spain. Although political regimes may be different in nature, it seems that 600 since WW2 different European states have used major rivers as a means to assert their political power 601 and authority both nationally and internationally.

602 We emphasize that the development of a major river may be influenced internationally by experience 603 gained with other rivers. International dynamics, such as the prestige of other countries, 604 decolonization, and cooperation over the Mediterranean Sea all had consequences for the landscapes 605 of the Rhône, intensifying the number of changes or leading to the creation of standards in the context 606 of globalization. These external events generated a top-down policy in which central government reproduced existing models, re-used previously abandoned projects, or created new ones. This dynamic is based on admiration, competition, and partnership.

609 Until the 1960s, this top-down policy was based on an image of the state as a strong executive power. 610 However, beginning in the 1960s, tension meant greater account had to be taken of the expectations of 611 local residents. Some local advocacy coalitions opposed this top-down policy and legitimized other 612 processes of discussion and problem-solving. These inhabitants were troubled to varying degrees by 613 the disappearance of landscapes for which they felt an attachment. Mobilization was structured around 614 four main issues: (i) agriculture and land dispossession, (ii) pollution and degradation of water quality, 615 (iii) flooding, and (iv) threats to certain historical activities. This discourse still feeds some 616 contemporary controversies and generates current demands made of the state and energy companies: 617 the ongoing ecological restoration of the Rhône fits into this context (Barthélémy and Armani 2015). 618 Some internal events, such as pollution and hydrologic extremes, have generated environmental 619 awareness and entailed new policies. The formation of heterogeneous collectives has brought together 620 different perceptions of environmental problems.

621 However, after the 1980s, media coverage of the Rhône River tended to fade, which might suggest 622 that the construction of a national project around the Rhône had been eclipsed. The state then 623 intervened during major crises (mainly flooding and pollution), operating in an emergency context and 624 in a less structured way. However, past developments and investments have largely structured the 625 river's landscapes and productive functions. 
Events must be viewed in a national setting in order to understand the current landscape, which reflects political and economic concerns and contexts. However, the mobilization of local inhabitants should not be forgotten: it has prevented even more extensive human transformation of the landscapes.

Socio-ecological fixes explore the relationships between crises, capitalist over-accumulation, and nature (Ekers and Prudham 2017). While political drivers are very powerful in shaping the development of the Rhône, it is clear that economic dynamics are also crucial, and this validates our second hypothesis. They determine many political choices.

The energy mix seems to be a good indicator for monitoring capital circulation and socio-ecological fixes along major rivers because it involves fixed capital (Harvey 2001). During the 1970s and 1980s, oil shocks entailed economic crises and the "necessity" of using more water, more nuclear energy, and less oil. The creation of more dams and five nuclear power plants is a footprint or proof that underlines the merging of "tertiary circuits" involving flows of capital into the reproduction of capitalism (Ekers and Prudham 2017). Dams and nuclear power plants are seen as spatially fixed capital contributing to energy supply and to economic independence.

643 We can question the possibility of an energy transition. In the face of the oil crises in the 1970s and 644 1980s, money flowed elsewhere. The circulation of capital was constant: production modes (dams,

645

646

647

648

649

650

651

652

653

654

655

656

657

658

659

660

661

662 nuclear power plants, wind turbines, micro-hydroelectric plants, and photovoltaic power stations) were superimposed, without necessarily replacing one another. There is no real succession in the Rhône valley despite the closure of Superphénix (a nuclear power plant), only accumulation.

This fix generated significant mobilization. Barthélémy (2006, p. 24) writes that the Brégnier-Cordon dam in the 1980s was the first case study of the Rhône River in which negotiations over environmental issues were very important because of its ecological value: the minimum flow of $100 \mathrm{~m}^{3} / \mathrm{s}$ was negotiated thanks to "environmentalist entrepreneurs", the CNR, and the ministry. The same actors could play different roles in the system because of their different social and political functions: one mayor was also a professor of geography, and another an ecologist and a professor of biology. Bouleau (2014) discussed this coproduction of scientific knowledge and waterscapes along the Rhône. The minimum flow was ascertained from indicators arrived at by compromise and negotiation (Fernandez 2014). Behind the numbers, minimum flow might give the impression that it is a scientific truth. These data arose as a choice involving different powers. Cubic meters per second were considered as a triumph of one camp over another: less water in the river would mean the economic agents had won with water being used for hydroelectricity and irrigation and consequently for making money. According to the environmentalist advocacy coalition, water is water, whereas in a more economic (and mainstream?) approach, water is energy and money. This reference to minimum flow synthesized different perceptions of the river, among them hydrological, political, economic, technical, 
social, or symbolic components. No one coalition won the amount of water it wanted, even if that number appeared as a victory for the environmentalists. As the minimum flow was higher, the energy company created micro-hydroelectric plants to partly offset lost production capacity and to make some money regardless. Thus, micro-hydroelectricity is a new mask for the hydroscalar fix (Swyngedouw 2014) because of the new places and plant that became productive. Advocacy coalitions can modify the trajectory of the production of nature and space, but perhaps only at a local scale, at the margins, and potentially for a limited period of time.

Urban waterfront revitalization projects can also be read as a socio-ecological fix at an urban-area scale. Lyon changed its parking lots into walkable spaces beside the Rhône in 2007 (Comby 2013). Here, the use of cars was abandoned so as to return the riverbanks to "the people". The new uses of these riverbanks are economically more cost-effective thanks to tourism, new restaurants, and bars. Socio-ecological fixes shed light on how city stakeholders have treated their riverfronts over time and how the spatial relations of city and river constrain (or not) relationships between urban populations and their rivers.

Methods with which to observe socio-ecological fixes are crucial. Most political ecology is based on historical analyses, studying "sedimented social relations" and environmental practices (Perreault et al. 2015). Even though our proxy has a bias, media discourse is quite efficient in reconstructing discursive trajectories and political strategies. Our results are very similar to those of Pritchard (2011), even though the perspectives are quite different. We assume that a national newspaper is an appropriate form of data if the topic under study is associated with national aims and measures.

\section{Conclusions}

This temporal approach to discourse in the national press aims to understand the landscape trajectories of the Rhône River from different angles. Politically, the river initially appeared to be a necessary medium for various top-down national strategies; but it has also become a medium for a more bottomup local policy to address new challenges such as environmental protection. Economically, the Rhône has been a resource that allows the region to be identified as a major contributor to the national economy, but it also reflects an excessive concentration of development, which may increase certain forms of vulnerability. Socially and culturally, the Rhône is the locus of historical practices, some of which are destabilized by the changes underway. Technically, the Rhône landscapes reflect a soughtafter mastery of natural elements by engineers, but the river is also a watercourse that cannot be fully tamed or totally purified. Physically, the new Rhône that has been developed embodies continuity with 
respect to the transversal dikes that have been in place since the nineteenth century; but it also embodies change because of the extent to which its course has been straightened.

The changing landscapes can be viewed in terms of power relationships associated with political and economic values. As for the Rhône riverscapes, navigation and energy entail new landscapes but also new risks. They are also linked with the industrialization of the valley. The location of energy development on the Rhône is an illustration of a hydroscalar fix: capitalism has generated the growth of new plant to produce energy and to transform water into a "valuable" resource. We insist on the materiality of socioecological fixes: different transformation schemes overlap and landscapes change forever. Currently, these anthropic changes of discharge and of channel and floodplain morphology are the principal threats to the Rhône (Lamouroux et al. 2015). Moore (2011) explains that capitalism is an "ecological regime" and could be thought of as a "world-ecology". We can surmise that the Rhône has (re)produced a capitalist ecology the creation of which can be monitored through historical archives such as newspapers.

\section{Acknowledgment}

We thank Fanny Arnaud, who collected historical maps and images.

\section{Funding}

This work was funded by the French program "Investissements d'Avenir" (ANR-11-LABX-0010), which is managed by the ANR. It was supported by the OHM Vallée du Rhône. This research project was part of a program of Rhône Basin Long-Term Ecosystem Research (LTER, ZABR). 


\section{References}

723

724

725

726

727

728

729

730

731

732

733

734

735

736

737

738

739

740

741

742

743

744

745

746

747

748

749

750

Ashmore, P. 2015. Towards a sociogeomorphology of rivers. Geomorphology 251: 149-156. https://doi.org/10.1016/j.geomorph.2015.02.020.

Bakker, K. 1999. Deconstructing Discourses of Drought. Transactions of the Institute of British Geographers 24 (3): 367-72. https://doi.org/10.1111/j.0020-2754.1999.t01-1-00367.x.

- 2002. From state to market?: water mercantilización in Spain. Environment and Planning A 34 (5): 767-790. https://doi.org/10.1068/a3425.

Barthélémy, C. 2006. De la restauration écologique à la concertation: des territoires fluviaux en devenir? Analyse sociologique du Programme décennal de restauration hydraulique et écologique du Rhône. Montpellier: IRSTEA.

Barthélémy, C., and G. Armani. 2015. A Comparison of Social Processes at Three Sites of the French Rhône River Subjected to Ecological Restoration. Freshwater Biology 60 (6): 1208-1220. https://doi.org/10.1111/fwb.12531.

Benzécri, J.-P., and F. Benzécri. 1980. L'analyse des données. Analyse des correspondances. Paris: Dunod.

Berelson, B. 1952. Content analysis in communication research. New York: Free Press.

Bethemont, J. 1972. Le thème de l'eau dans la vallée du Rhône: essai sur la genèse d'un espace hydraulique. Lyon: Impr. Le feuillet blanc.

Boholm, M. 2009. Risk and Causality in Newspaper Reporting. Risk Analysis 29 (11): 1566-77. https://doi.org/10.1111/j.1539-6924.2009.01296.x.

Bok, R. 2018. 'By our metaphors you shall know us': The 'fix' of geographical political economy. Progress in Human Geography : 1-22. https://doi.org/10.1177/0309132518804352

Bouleau, G. 2014. The co-production of science and waterscapes: The case of the Seine and the Rhône Rivers, France. Geoforum 57: 248-257. https://doi.org/10.1016/j.geoforum.2013.01.009.

Boyer, A.-L., E. Comby, S. Flaminio, Y.-F. Le Lay, and M. Cottet. 2018. The social dimension of a river's environmental quality assessment. Ambio. https://doi.org/10.1007/s13280-018-1089-9.

Boykoff, M. T. 2011. Who Speaks for the Climate? Making Sense of Media Reporting on Climate Change. Cambridge: Cambridge University Press. 
Boykoff, M. T., and J. M. Boykoff. 2007. Climate change and journalistic norms: A case-study of US mass-media coverage. Geoforum 38 (6): 1190-1204. https://doi.org/10.1016/j.geoforum.2007.01.008.

Bravard J.-P. 2010. Discontinuities in braided patterns: The River Rhône from Geneva to the Camargue delta before river training, Geomorphology 117: 219-233. https://doi.org/10.1016/j.geomorph.

2009.01.020.

Bréthaut, C., and G. Pfliger. 2013. The shifting territorialities of the Rhône River's transboundary governance: a historical analysis of the evolution of the functions, uses, and spatiality of river basin governance. Regional Environmental Change 15 (3): 549-558. https://doi.org/10.1007/s10113-0130541-4.

Brossard, D., J. Shanahan, and K. McComas. 2004. Are Issue-Cycles Culturally Constructed? A Comparison of French and American Coverage of Global Climate Change. Mass Communication and Society 7 (3): 359-377. https://doi.org/10.1207/s15327825mcs0703_6.

Budds, J. 2009. Contested H2O: Science, policy and politics in water resources management in Chile. Geoforum 40 (3): 418-430. https://doi.org/10.1016/j.geoforum.2008.12.008.

Callon, M. 1986. Eléments pour une sociologie de la traduction. La domestication des coquilles SaintJacques et des marins-pêcheurs dans la baie de Saint-Brieuc. L'Année sociologique 36: 169-208.

Castree, N., and B. Christophers. 2015. Banking Spatially on the Future: Capital Switching, Infrastructure, and the Ecological Fix. Annals of the Association of American Geographers 105 (2): 378-386. https://doi.org/10.1080/00045608.2014.985622.

Cohen, A., and K. Bakker. 2014. The Eco-Scalar Fix: Rescaling Environmental Governance and the Politics of Ecological Boundaries in Alberta, Canada. Environment and Planning D: Society and Space 32 (1): 128-146. https://doi.org/10.1068/d0813.

Comby, E. 2013. Les discours de presse sur les reconquêtes du Rhône lyonnais (Le Progrès, 20032010). Géocarrefour 88 (1): 31-43.

Comby, E., Y.-F. Le Lay, and H. Piégay. 2014a. The Achievement of Decentralized Water Management Through Broad Stakeholder Participation. An Example from the Drôme River Catchment Area in France (1981-2008). Environmental Management 54: 1074-89. https://doi.org/10.1007/s00267-014-0378-8.

- 2014b. How Chemical Pollution Becomes a Social Problem. Risk Communication and Assessment through Regional Newspapers during the Management of PCB Pollutions of the Rhône 
River (France). Science of The Total Environment 482-483: 100-115.

783 https://doi.org/10.1016/j.scitotenv.2014.02.137.

784 Cottet, M., F. Piola, Y.-F. Le Lay, S. Rouifed, and A. Riviere-Honegger. 2015. How Environmental

785 Managers Perceive and Approach the Issue of Invasive Species: The Case of Japanese Knotweed s.l.

786 (Rhône River, France). Biological Invasions 17 (12): 3433-3453. https://doi.org/10.1007/s10530-015-

787 0969-1.

788 Ekers, M., and S. Prudham. 2015. Towards the socio-ecological fix. Environment and Planning A 47

789 (12): 2438-2445. https://doi.org/10.1177/0308518X15617573.

790 2017. The Metabolism of Socioecological Fixes: Capital Switching, Spatial Fixes, and the

791 Production of Nature. Annals of the American Association of Geographers 107 (6): 1370-1388.

792 https://doi.org/10.1080/24694452.2017.1309962.

793 Fairclough, N. 2010. Critical Discourse Analysis: The Critical Study of Language. New York: 794 Longman.

795 Fernandez, S. 2014. Much Ado About Minimum Flows...Unpacking indicators to reveal water 796 politics. Geoforum 57: 258-71. https://doi.org/10.1016/j.geoforum.2013.04.017.

797 Foucault, M. 1966. Les mots et les choses. Une archéologie des sciences humaines. Paris: Gallimard.

798 1971. L'ordre du discours : Leçon inaugurale au Collège de France prononcée le 2 décembre 799 1970. Paris: Gallimard.

800 Frioux, S., and V. Lemire. 2012. Pour une histoire politique de l'environnement au 20e siècle.

801 Vingtième siècle 1 (113): 3-12.

802 Giandou, A. 1999. La compagnie nationale du Rhône (1933-1998). Histoire d'un partenaire régional 803 de l'Etat. Saint-Martin-d'Hères: Presses Universitaires de Grenoble.

804 Gregory, K. J., and H. Rowlands. 1990. Have global Hazards increased? Geography review 4 (2): $805 \quad 35-38$.

806 Harvey, D. 1996. Justice, Nature and the Geography of Difference. Oxford: Blackwell.

807 2001. Globalization and the spatial fix. Geographische revue 2 (3): 23-31.

808 Hayward, R., and B. S. Osborne. 1973. The British Colonist and the Immigration to Toronto of 1847:

809 A Content Analysis Approach to Newspaper Research in Historical Geography. Canadian 810 Geographer 17 (4): 391-402. https://doi.org/10.1111/j.1541-0064.1973.tb00201.x. 
Heiden, S. 2010. The TXM Platform: Building Open-Source Textual Analysis Software Compatible with the TEI Encoding Scheme. 24th Pacific Asia Conference on Language, Information and Computation, $10 \mathrm{p}$.

Hilgartner, S., and C. L. Bosk. 1988. The Rise and Fall of Social Problems: A Public Arenas Model. American Journal of Sociology 94 (1): 53-78. https://doi.org/10.2307/2781022.

Ibsen, M.-L., and D. Brunsden. 1996. The nature, use and problems of historical archives for the temporal occurrence of landslides, with specific reference to the south coast of Britain, Ventnor, Isle of Wight. Geomorphology 15 (3-4): 241-58. https://doi.org/10.1016/0169-555X(95)00073-E.

Lamouroux, N., J. A. Gore, F. Lepori, and B. Statzner. 2015. The Ecological Restoration of Large Rivers Needs Science-based, Predictive Tools Meeting Public Expectations: An Overview of the Rhône Project. Freshwater Biology 60 (6): 1069-1084. https://doi.org/10.1111/fwb.12553.

Lave, R. 2015. Introduction to Special Issue on Critical Physical Geography. Progress in Physical Geography 39 (5): 571-575. https://doi.org/10.1177/0309133315608006.

Lave, R., M. W. Wilson, E. S. Barron, C. Biermann, M. A. Carey, C. S. Duvall, L. Johnson, et al. 2014. Intervention: Critical Physical Geography. The Canadian Geographer 58 (1): 1-10. https://doi.org/10.1111/cag.12061.

Lebart, L., A. Salem, and L. Berry. 1998. Exploring Textual Data. Dordrecht: Springer.

Leopold, A. 1949. A Sand County Almanac and Sketches Here and There. Oxford: Oxford University Press.

Lester, L. 2010. Media and environment: conflict, politics and the news. Cambridge: Polity.

Mayring, P. 2000. Qualitative Content Analysis. Forum: Qualitative Social Research / Sozialforschung 1 (2): 1-10.

Merrill, J. C. 2000. Les quotidiens de référence dans le monde. Les Cahiers du Journalisme, 7: 10-15.

Mitchell, D. 2003. Dead Labor and the Political Economy of Landscape - California Living, California Dying. In Handbook of Cultural Geography, K. Anderson, M. Domosh, S. Pile and N. Thrift, 233-248. London: SAGE Publications Ltd. https://doi.org/10.4135/9781848608252.

Moore, J. W. 2011. Transcending the metabolic rift: a theory of crises in the capitalist world-ecology. The Journal of Peasant Studies 38 (1): 1-46. https://doi.org/10.1080/03066150.2010.538579.

Mukerji, C. 2009. Impossible Engineering: Technology and Territoriality on the Canal du Midi. Princeton, Princeton University Press. 
841 O'Neill, K. M. 2006. Rivers by Design: State Power and the Origins of U.S. Flood Control. Durham

842 N.C.: Duke University Press Books.

843 Perreault, T. G. Bridge, and J. McCarthy. 2015. The Routledge Handbook of Political Ecology.

844 London: Routledge.

845 Pritchard, S. B. 2004. Reconstructing the Rhône: The Cultural Politics of Nature and Nation in 846 Contemporary France, 1945-1997. French Historical Studies 27 (4): 765-799.

847 2011. Confluence: The Nature of Technology and the Remaking of the Rhône. Cambridge,

848 Mass: Harvard University Press.

849 Ratinaud, P., and P. Marchand. 2012. Application de la méthode ALCESTE aux "gros" corpus et 850 stabilité des "mondes lexicaux" : analyse du "CableGate" avec IRAMUTEQ. Lexicometrica, 10 p.

851 Reinert, M. 1983. Une méthode de classification descendante hiérarchique : application à l'analyse 852 lexicale par contexte. Les cahiers de l'analyse de données 8 (2): 187-198.

853 Sabatier, P. A. 1988. An Advocacy Coalition Framework of Policy Change and the Role of Policy854 Oriented Learning Therein. Policy Sciences 21 (2-3): 129-168. https://doi.org/10.1007/BF00136406.

855 2010. Advocacy Coalition Framework (ACF). In Dictionnaire des politiques publiques, L. 856 Boussaquet, S. Jacquot and P. Ravinet (dir.), 49-57. Paris: Presses de Sciences Po.

857 Sabatier, P. A., and H. C. Jenkins-Smith. 1993. Policy Change and Learning: An Advocacy Coalition 858 Approach. Boulder, Colo.: Westview Press.

859 Smith, N. W., and H. Joffe. 2009. Climate change in the British press: the role of the visual. Journal of 860 Risk Research 12 (5): 647-663. https://doi.org/10.1080/13669870802586512.

861 Swyngedouw, E. 1999. Modernity and Hybridity: Nature, Regeneracionismo, and the Production of 862 the Spanish Waterscape, 1890-1930. Annals of the Association of American Geographers 89 (3): 863 443-465. https://doi.org/10.1111/0004-5608.00157.

864 2013. Into the Sea: Desalination as Hydro-Social Fix in Spain. Annals of the Association of 865 American Geographers 103 (2): 261-270. https://doi.org/10.1080/00045608.2013.754688.

866 2014. "Not A Drop of Water...": State, Modernity and the Production of Nature in Spain, 867 1898-2010. Environment and History $20 \quad$ (1): 868 https://doi.org/10.3197/096734014X13851121443445

869 2015. Liquid Power: Contested Hydro-Modernities in Twentieth-Century Spain. Cambridge: 870 MIT Press. 
871 Thorel, M, H. Piégay, C. Barthélémy, B. Räpple, C.-R. Gruel, P. Marmonnier, et al. 2018. Socio872 environmental implications of process-based restoration strategies in large rivers: should we remove 873 novel ecosystems along the Rhône (France)?. Regional Environmental Change 18: 2019-2031. 874 https://doi.org/10.1007/s10113-018-1325-7.

875 Vuorisalo, T., R. Lahtinen, and H. Laaksonen. 2001. Urban Biodiversity in Local Newspapers: A 876 Historical Perspective. Biodiversity \& Conservation $10 \quad$ (10): 1739-1756.

877 https://doi.org/10.1023/A:1012099420443.

878 Weinberg, A. M. 1967. Can Technology Replace Social Engineering?. Bulletin of the Atomic 879 Scientists 22 (10): 4-8. http://dx.doi.org/10.1080/00963402.1966.11454993.

880 
883 Figure 1. Historical maps and images of the Rhône riverscapes at Saint-Montan (Ardèche, France)
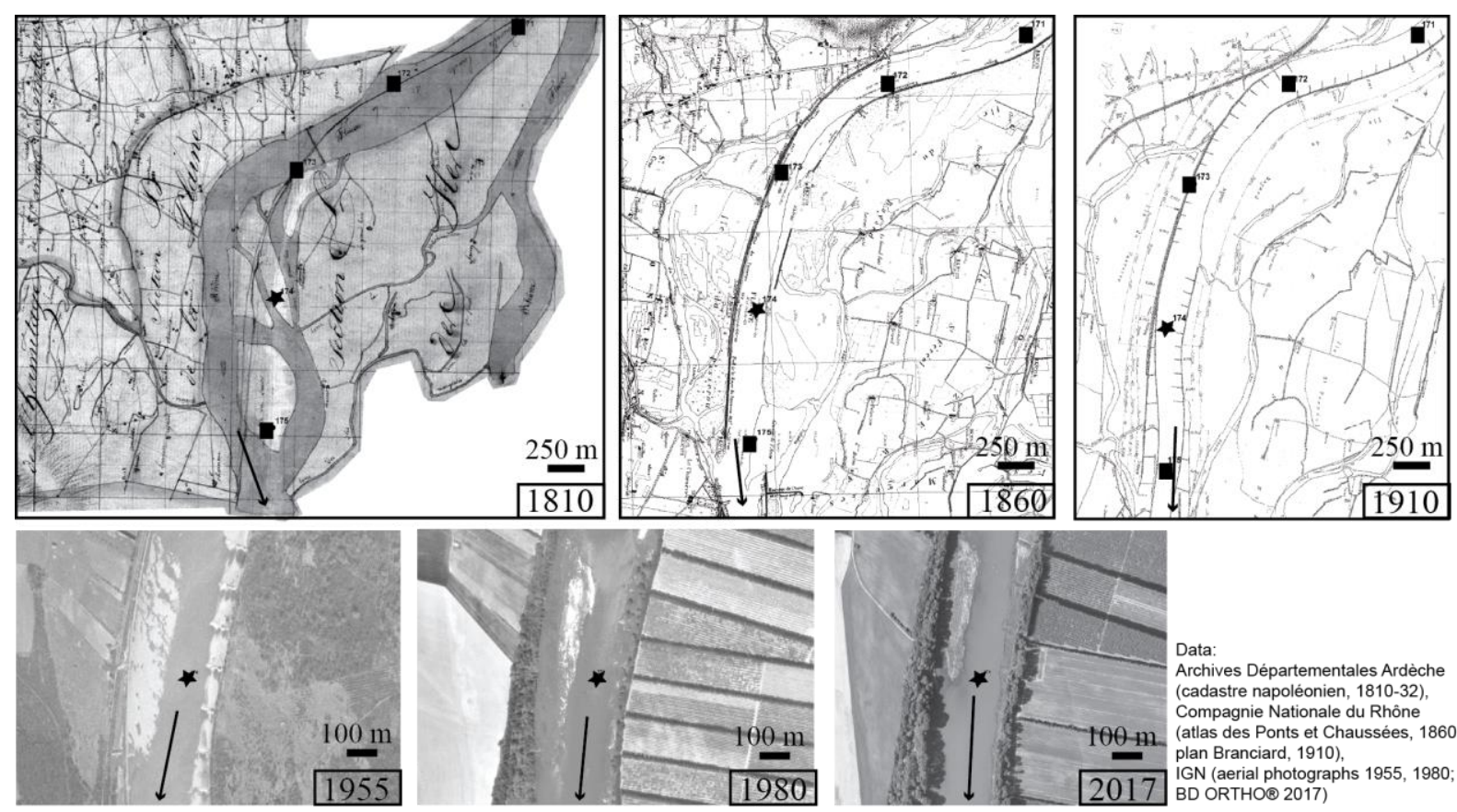

Data:

Archives Départementales Ardèche Compagnie Nationale du Rhône (atlas des Ponts et Chaussées, 1860 plan Branciard, 1910)

GN (aerial photographs 1955, 1980; 
885 Figure 2. Location map of the Rhône River valley

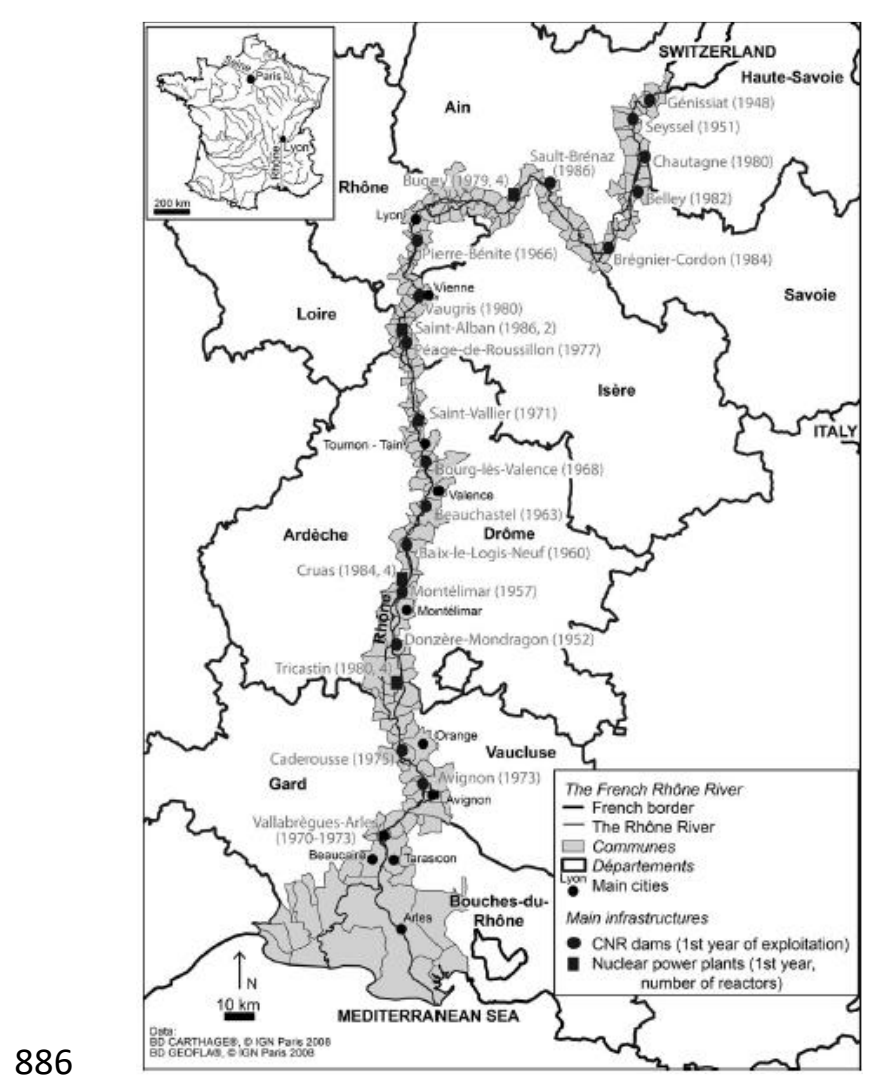


887 Figure 3. Distribution of articles about the Rhône River from 1945 to 2013 in Le Monde $(\mathrm{n}=1,079)$

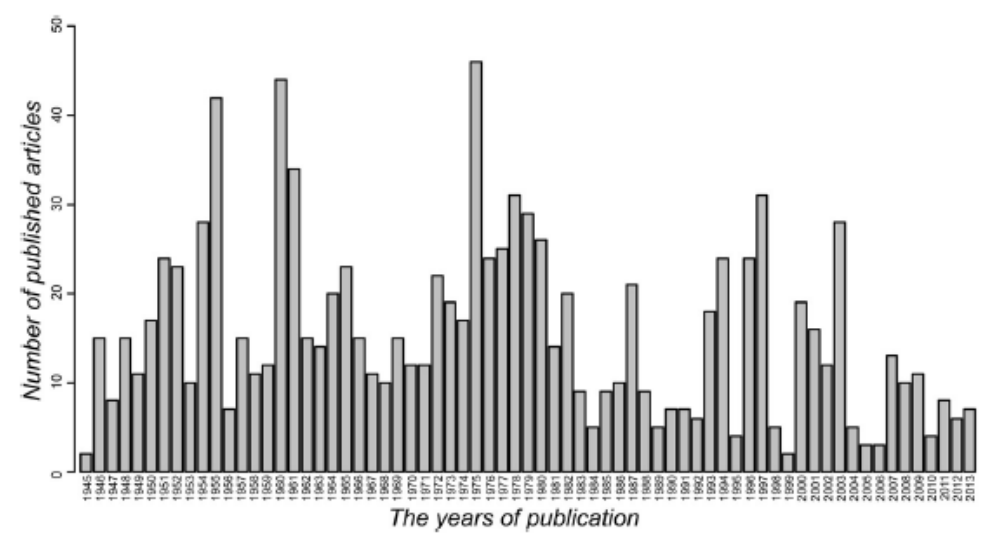


889 Figure 4. Main topics from 1945 to 2013 in Le Monde (n=1,079)

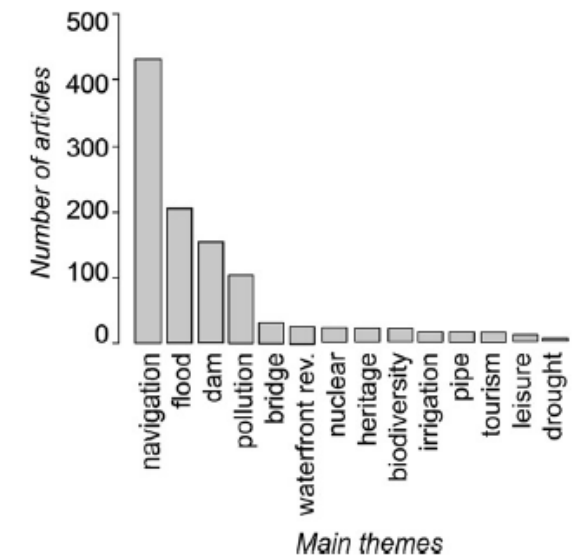


891 Figure 5. Temporal variations in themes expressed by articles focused on the Rhône River
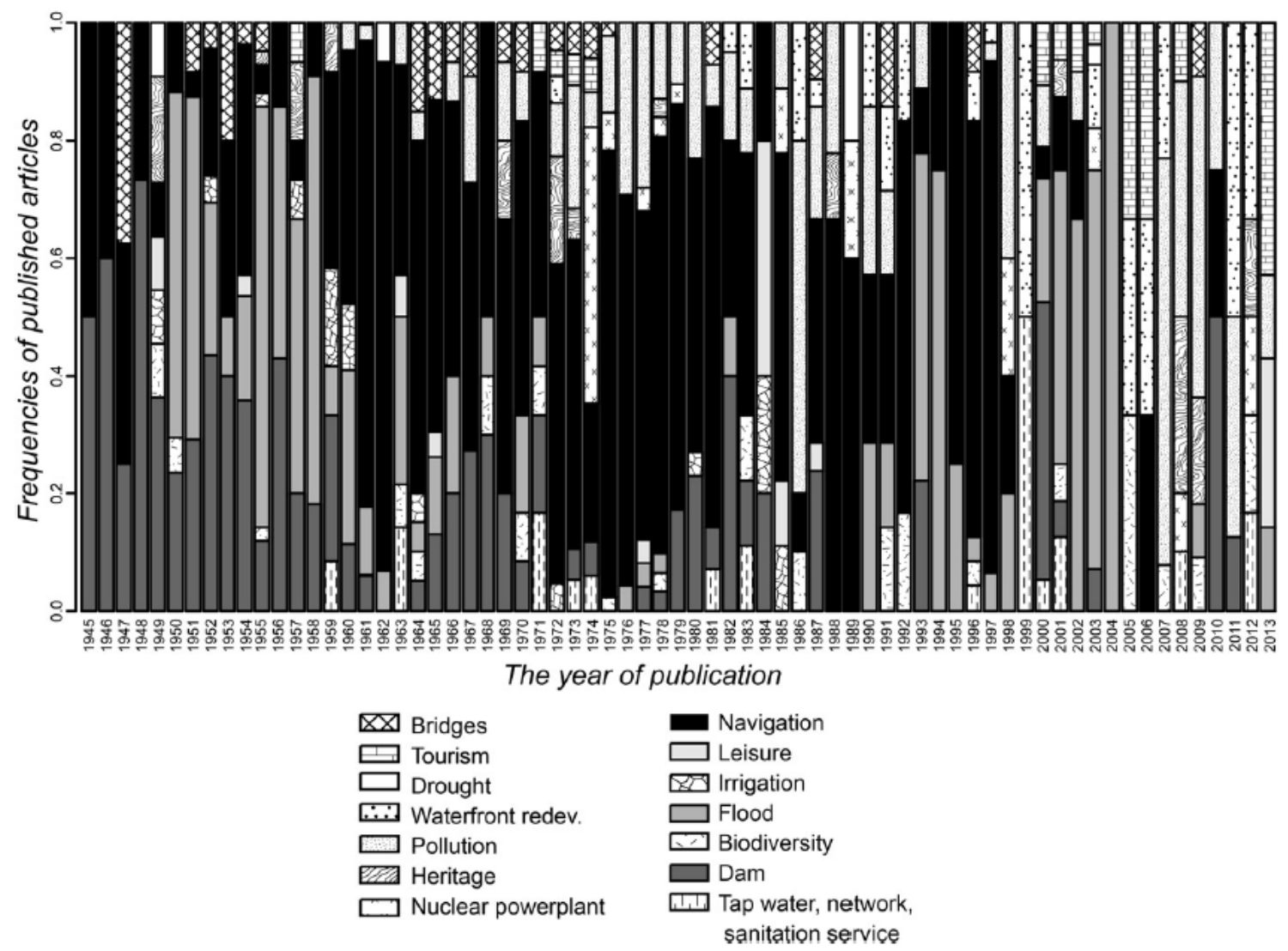
893 Figure 6. Clustering tree after a top-down hierarchical clustering on Le Monde (1945-2013)

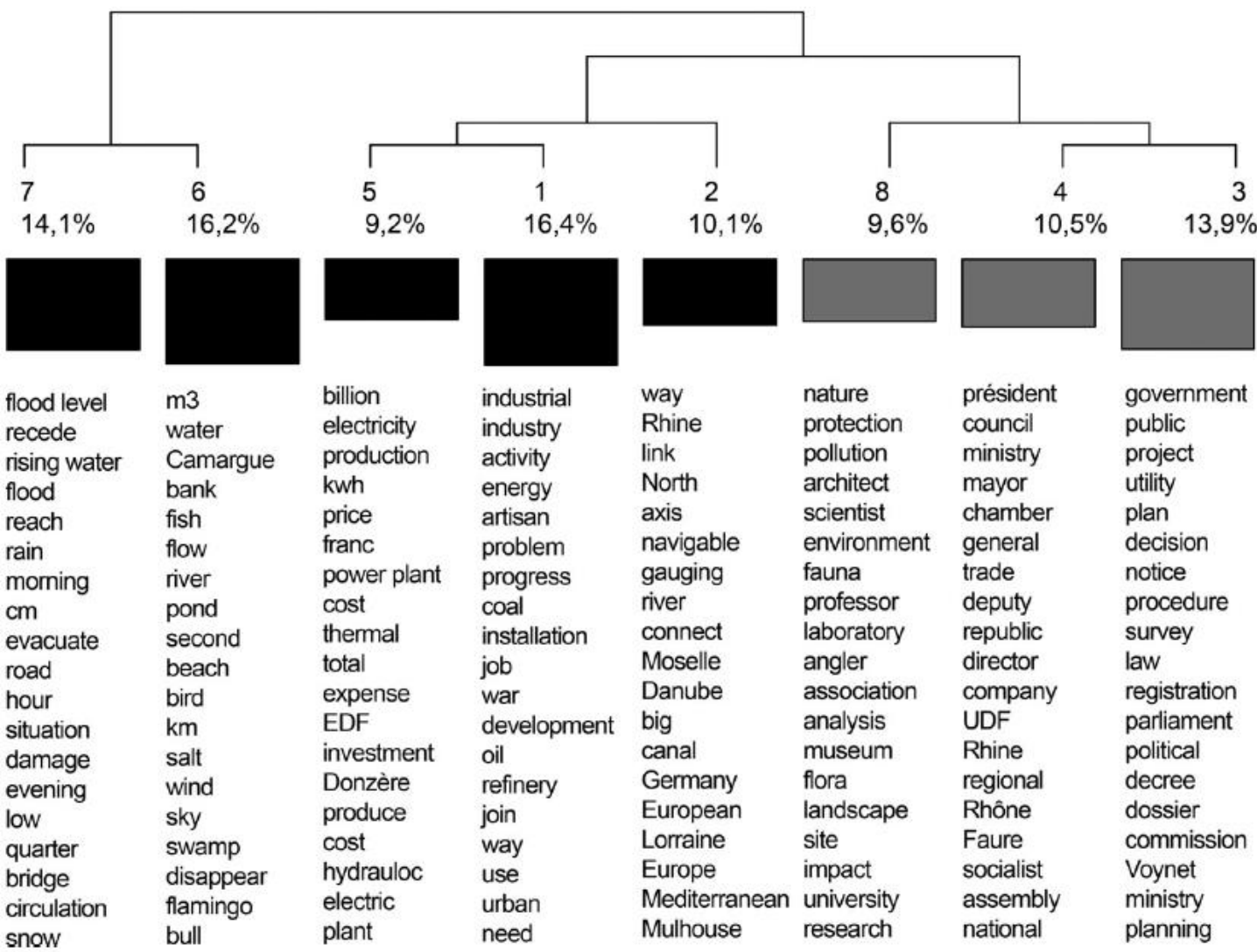


896 Figure 7. Word clouds of toponyms in Le Monde (1945-2013)

\begin{tabular}{|c|c|}
\hline Toponyms of the Rhône River catchment & Toponyms outside the Rhône River catchment \\
\hline 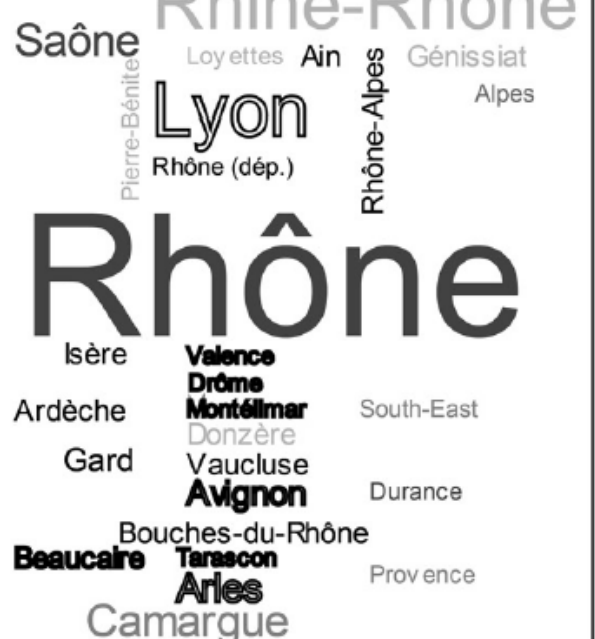 & 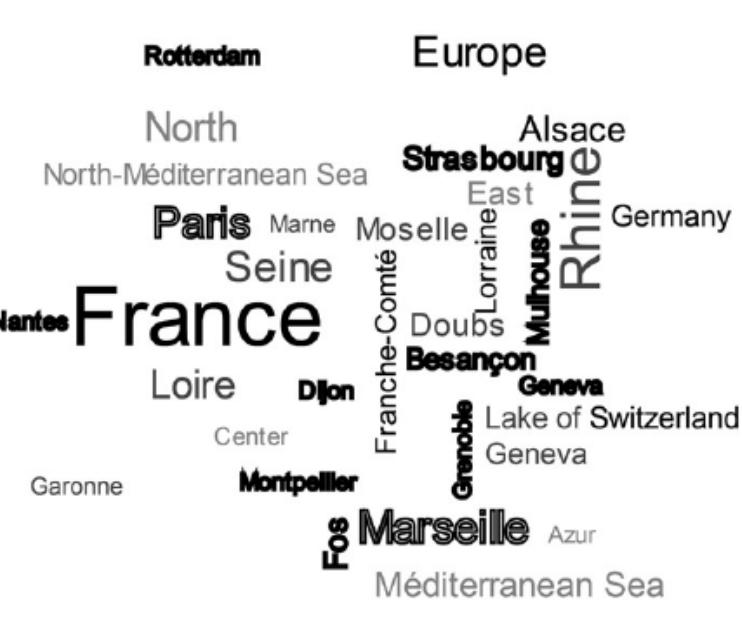 \\
\hline $\begin{array}{l}\text { Types of toponyms } \\
\text { Department and } \mathrm{r} \\
\text { Cities } \\
\text { Rivers and lake } \\
\text { Dams and canals } \\
\text { Regions or blurre }\end{array}$ & $\begin{array}{l}\text { Number of quotations } \\
\text { L } 710 \text { occurrences } \\
\text { Arles } 270 \text { occurrences } \\
\text { Isère } 121 \text { occcurrences } \\
\text { Azur } 70 \text { occcurrences }\end{array}$ \\
\hline
\end{tabular}

